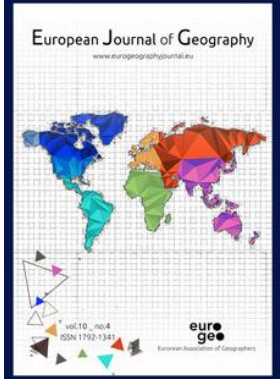

European Journal of Geography

Volume 11, Issue 2, pp. 123 - 136

Article Info:

Received: 03/09/2020; Accepted: 12/12/2020

Corresponding Authors: * peter.kumer@gov.si

https://doi.org/10.48088/ejg.p.kum.11.2.123.136

\title{
Hidden geographies of social justice in an urban environment: the particularities of naturally-occurring arts districts
}

Peter KUMER ${ }^{1 *}$,

${ }^{1}$ Ministry of Education, Science and Sport, Slovenia

\section{Keywords:}

hidden geographies, right to the city, just city, cultural quarters, creativity, urban geography

\begin{abstract}
Despite extensive research on the role arts districts play in the economic development of cities, little is known about the dynamics of social interactions within those districts and their impact on society. Drawing on 26 interviews with actors and stakeholders of arts districts in Ljubljana, this paper explores the role of arts districts in creating a just city. Four dimensions of such districts, which represent the meaningful themes that emerged from the data, are examined. The first dimension is the interrelationship of artists, cultural workers and activists. The second dimension encompasses mutual support and forms of self-governance, whereas the third dimension investigates the role arts districts play in the neighbourhood. The fourth dimension seeks to define the role of arts districts as part of urban development generally driven by capital. The results show that arts districts are important in the struggle for the right to the city. Actors from these districts are committed to addressing the causes of social inequality at their root via artist-led civic engagement activities.
\end{abstract}

The publication of the European Journal of Geography (EJG) is based on the European Association of Geographers' goal to make European Geography a worldwide reference and standard. Thus, the scope of the EJG is to publish original and innovative papers that will substantially improve, in a theoretical, conceptual or empirical way the quality of research, learning, teaching and applying geography, as well as in promoting the significance of geography as a discipline. Submissions are encouraged to have a European dimension. The European Journal of Geography is a peer-reviewed open access journal and is published quarterly. 


\section{INTRODUCTION}

Social inequalities resulting from capitalist competition are among the biggest challenges facing cities around the world today. Many urban planners have struggled to lay the foundations for just cities, a term that describes urban areas which enable equity, democracy and diversity (Müller, 2019), with several concepts having been developed to achieve this goal (Bartzokas-Tsiompras \& Photis 2020, BartzokasTsiompras \& Photis, 2019). For example, "Creative Placemaking" (Markusen and Gadwa, 2010) is recognised as an important urban place-based initiative that affects power relations in urban environments. "Hacks" (Hofmann et al., 2012) are playful actions in which people step into active, agentic roles and alter and disrupt the taken-for-granted code of the city.

The idea of involving artists in urban planning was supported by Webb (2014), who noted that "artists are storytellers, preservers of cultural identity and critics of the injustices that cause humanity to stagnate". In addition, Redaelli (2019) argues that the arts are a valuable tool for building social networks, challenging political regimes, and reforming and subverting social values worldwide. Verson (2007) describes the phenomenon as cultural activism, a way of organising in which art, activism, performance and politics meet, mingle, and interact.

Arts districts denote a complex urban agglomeration of activities, primarily arts and culture, but not exclusively. They are often located in post-industrial areas in the inner city. Such districts are urban commons, a term that describes collective actions, shared resources without clear property rights, and social movements that counteract market and governmental actions. As such, they touch on a variety of social issues like collectivism, diversity, power, atmosphere, government, sexuality, inclusion, etc. (Borch and Kornberger, 2015). In this paper, they are discussed in terms of their role in the struggle for the right to the city, an idea first proposed by Lefebure (1968). The right to the city in the case of an arts district means negotiating the creation of a space that allows self-expression and autonomy of the various actors (i.e. individuals and groups that are active in arts districts) in that district. All of these aspects are part of hidden geographies of the city, with the main stress on the spatial dimension, namely the key interest of geographers. Arts districts have so far chiefly been of interest to fields such as urban sociology, economics and urban planning. As argued by Agnew (1995), these fields within the social sciences have not been "spaceless" but filled with "unacknowledged" geographical assumptions. These hidden geographies of different currents of social thought are emphasised in this paper since they help to see and determine patterns in the complex relationships between people and their environment, such as between actors and their arts districts.

In European and North American cities, arts districts are often developed or supported by urban planners who want to revitalise certain areas through creativity (Montgomery, 2003; Euans, 2009; Lavanga, 2013). However, they more often emerge spontaneously after a series of uncoordinated decisions that lead to establishing their activities in these inspirational and inexpensive spaces. They are characterised by a free spirit, political freedom and avant-garde cultural production (Murzyn-Kupisz, 2012). A certain form of self-governance is necessary because members of these districts are distrustful of regulation and wish to be fully immersed in their creative activities (Zukin and Braslow, 2011; Kumer, 2020). For this reason, a special type of arts district-the 
naturally-occurring district-has set itself the goal of achieving political autonomy (Kumer, 2020).

In order to fully understand the blending of creative practice with social and political activism, one must look at how they emerge and evolve over time. Four arts districts in Ljubljana developed from a grassroots approach. The earliest bundling of artistic and cultural forces took place in 1989 with a social initiative called Mreža za Metelkova, which aimed to provide a place for more than 200 artists and cultural workers who did not have suitable working spaces. The unfulfilled promise of the city administration to convert the large, former military barracks into artists' studios on Metelko Street was followed by an illegal occupation. Those involved, who started to hold concerts, artistic exhibitions, political debates and social activities, proclaimed Metelkova an autonomous alternative arts zone (Bibič, 2003; Žagar, 2006; Babić, 2013).

Later, a similar occupation took place in Rog, a former bicycle factory. In March 2006, the city administration allowed artists, cultural workers and activists (who had formed an informal group called TEMP) to temporarily use the abandoned industrial halls. Over the next decade, the municipality developed a plan to transform Rog into a centre of contemporary arts together with a hotel, apartments and a shopping mall. Yet the mainly younger generation of artists refused to move out and support the municipality's plan (Ehrlich et al., 2012; Tosics, 2016). The mayor stated that "Ljubljana doesn't need another Metelkova", adding fuel to the already heated debate that the root of the problem lay in a shortage of appropriate and affordable working spaces for artists and creative workers.

The other two arts districts, Tobačna and Križeuniška, are examples of a mixed, citydesignated and grassroots approach to the formation of a district (Kumer, 2020). Tobačna, previously a tobacco factory, was bought by a construction company soon after it closed in 2004. The company went into receivership but started to rent out its premises to arts, cultural and creative professionals (TOBACNA City, 2012; Old Ljubljana Tobacco Factory, 2015). Recently, their rental contracts were cancelled as the plan to convert the area into residential and commercial property progressed (Halilović and Cerar, 2020). Križeuniška is one of the oldest residential streets in Ljubljana and has always been home to prominent figures from Slovenian literature and intellectual circles (Mreulje, 2015). It was only with the arrival of a theatre group in 2011, which started to bring people together through a street greening project, that the street attracted new artists and cultural workers. The idea of proclaiming the area a cultural district was supported by the city administration by converting city-owned apartments into artists' studios and providing financial support for the project.

Previous literature on naturally-occurring arts districts has mainly analysed their role in the city development (Murzyn-Kupisz, 2012; Borrup, 2015; Redaelli, 2019). Their direct influence on urban development has been discussed through the positive impact of the creative industries' arrival on the housing market and the popularity of the area. The oft-discussed flip side is gentrification, which comes after artists have moved into an area (Vazquez, 2002). However, these discussions rarely touch on the views of actors from arts districts who criticise the city's commercialisation and social differentiation. The specific character of arts districts, which influences public debates on pressing social issues, has been neglected.

Hence this paper attempts to unravel hidden geographies of arts districts. It examines the role of arts districts in creating a just city by exploring their four 
dimensions using geographic terminology. The dimensions are the meaningful themes that emerged from the data. The first dimension explores the interdependence of artists, cultural workers and activists. Creative forms of social and political activism have been observed in different cities. For example, Buser et al. (2013) found that the mixing of creative and cultural interests with activism leads to establishing of an attractive urban space. The second dimension encompasses mutual support and forms of selfgovernance. The importance of the social interactions that develop within arts districts has been the focus of several studies (Currid and Williams, 2010; Zarlenga et al., 2016). Gordon and McCann (2000) studied social networks within economic clusters and found that companies are willing to act as a group to support mutually beneficial goals. Such cooperation, when supported by an autonomous atmosphere, generates creativity (García et al., 2015). The third dimension investigates the role arts districts play in the neighbourhood. While the literature generally supports the notion that arts districts are positively received by urban residents since they bring a variety of mostly economic benefits (Florida, 2002; Markusen and Schrock, 2006; Scott, 2008; Polèse, 2012), the media in particular presents naturally-occurring districts as contested spaces in the urban space (Panjan, 2016; Niranjan, 2015). The fourth dimension attempts to define the role of an arts district in urban development generally driven by the profit motive. If they come to be regarded as artistic, they often become the subject of gentrification and rising property prices (Mathews, 2010; Rich and Tsitsos, 2016).

\section{METHODS}

In this paper, we use interview data from fieldwork conducted between July 2015 and April 2016 in Ljubljana, the capital and largest city of Slovenia. To find interviewees, we employed snowball sampling, as further explained in a paper by Kumer (2020). A total of 30 interviews were conducted. In three cases, more than one person was present at the interview and therefore 36 people were interviewed in total. Most were activists, artists and designers (actors) who work and, in some cases, live in Ljubljana arts districts (Table 1). Four of them were stakeholders working in the arts sector; two of the stakeholders were officials from the city administration and two were non-profit organisations involved in arts and cultural renewal projects (Table 2).

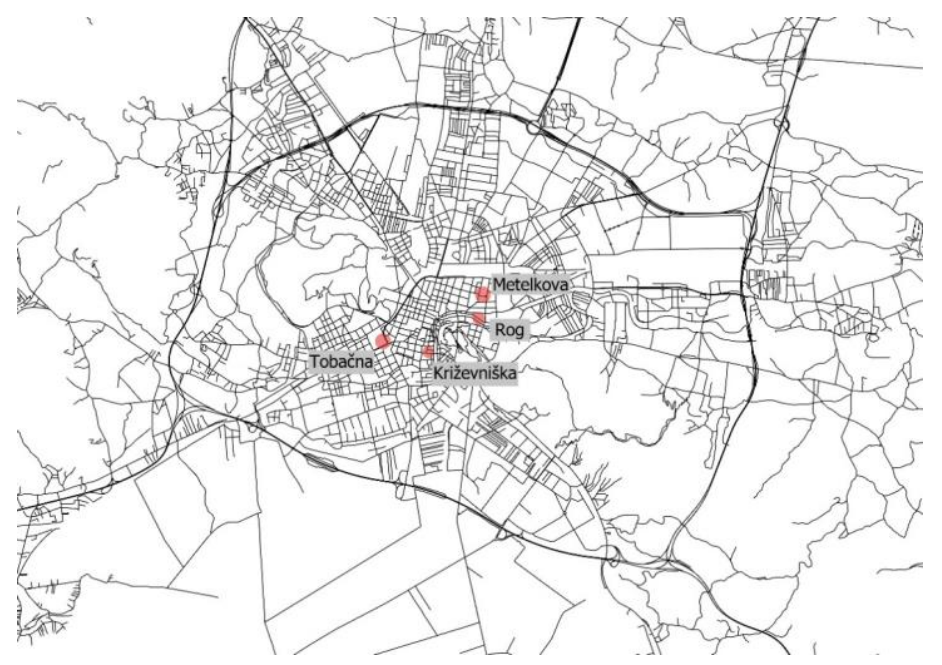

Figure 1. Naturally-occurring arts districts in Ljubljana 
Five arts districts were studied (Kumer, 2020), but for the purposes of this paper only naturally-occurring arts districts (Figure 1) were further analysed (Rog, Metelkoua, Tobačna, Križeuniška). As an entirely city-designated district, Kino Šiška is not part of this study. Therefore, four interviews (6 persons) are not relied on in this study. I used social networks and social media posts to find participants who were active in these districts. The ongoing referral process continued until at least four interviews had been completed in each district while respecting additional parameters to ensure a diversity of artistic and cultural activity. The data I used come from semistructured interviews, each lasting around 45 minutes. The interview transcriptions were coded and analysed using the ATLAS.ti 8 software.

Table 1. Demographic and social details of the interviewed actors

\begin{tabular}{|c|c|c|c|}
\hline Arts district & Gender & Year of birth & Type of activity \\
\hline \multirow[t]{7}{*}{ Križeuniška } & $\mathrm{M}$ & 1976 & research organisation for visual interventions in space \\
\hline & M & 1961 & museum \\
\hline & M & 1965 & theatre \\
\hline & $\mathbf{F}$ & 1975 & fashion design collective \\
\hline & M & 1968 & letterpress studio \\
\hline & $\mathrm{M}$ & 1980 & hair artist salon \\
\hline & $\mathbf{F}$ & 1985 & sculptress \\
\hline \multirow[t]{5}{*}{ Rog } & $\mathrm{M}$ & 1990 & street dance group \\
\hline & M & 1992 & circus collective \\
\hline & $\mathbf{F}$ & 1984 & sculptress and actress \\
\hline & M & 1992 & painter and event organiser \\
\hline & $\mathbf{F}$ & 1975 & immigrant support centre \\
\hline \multirow[t]{4}{*}{ Tobačna } & $M, M$ & 1966, 1960 & sound and visual arts collective \\
\hline & $\mathrm{F}, \mathrm{F}$ & 1988,1989 & stone and soapmaking studio \\
\hline & M & 1985 & coworking space \\
\hline & $\mathbf{F}$ & 1967 & museum \\
\hline \multirow[t]{6}{*}{ Metelkova } & $\mathbf{F}$ & 1984 & concert venue and music publishing \\
\hline & $\mathbf{F}$ & 1977 & concert venue and theatre \\
\hline & $\mathrm{M}$ & 1983 & LGBT rights group \\
\hline & $F, F, M$ & $\begin{array}{ll}1975,1980, \\
1976\end{array}$ & $\begin{array}{l}\text { gallery, plastic arts platform and feminist rights } \\
\text { activism }\end{array}$ \\
\hline & $\mathrm{M}$ & 1962 & cultural activist and concert organiser \\
\hline & M & 1956 & video and multimedia artist \\
\hline
\end{tabular}

Table 2. Main details of the interviewed stakeholders

\begin{tabular}{|l|l|l|}
\hline Gender & Role in service & Service \\
\hline M & decision-maker & city administration \\
\hline F & decision-maker & city administration \\
\hline F & non-profit organisation & arts and cultural renewal project \\
\hline F & non-profit organisation & arts and cultural renewal project \\
\hline
\end{tabular}

\section{RESULTS}

Arts districts produce a set of narratives that play a key role in shaping their character. In this section, four dimensions of arts districts are analysed with respect to social justice. These dimensions represent the themes that emerged from the data during the coding process. 
The first section scrutinises how actors cooperate and why an arts district comprises a mash-up of different activities, not only limited to arts and culture. The second section considers types of mutual support and forms of self-governance. The third section investigates problems and the relationship between actors and residents that live in close proximity to arts districts. In the fourth section, we place arts districts in the centre of the debate on the increased commercialisation of urban space.

\subsection{Interdependence of different disciplines, networking and engagement among actors}

In every arts district examined, an attempt was made to bring together individuals and groups engaged in different activities. Although mainly artists and cultural workers form the core of the districts, activists, support centres for different vulnerable groups, and sports groups were equally involved in the process of forming the district.

A hair artist from Križeuniška noted that they wanted to clean their street and bring in flowers and benches, so they cooperated on raising funds: "Every year, we organised an open day event, invited $a D J$ and organised catering. It was a fundraising campaign for our street, in which almost all the neighbours took part. As a prize, our studio offered hairstyling, the restaurant next door offered dinners, the theatre gave tickets for their show, and fashion designers contributed their T-shirts."

A similar form of collaboration was described by a painter and event organiser, one of our interviewees from Rog, who, when talking about synergies between activities, said that "each group strives to find another to work with. We worked with an immigrant support centre, designing posters for advertising campaigns and organising wall-painting sessions."

However, there is a continuous discussion among the individuals, groups and collectives about who belongs to the district and who does not. The way Rog was internally organised was criticised by one member of a sound and visual arts collective who later moved to Tobačna. At Rog, they were squatters, but at Tobačna they became tenants. He noted that "[at Rog] every year there were power games where some groups tried to gain some kind of control over how Rog was presented to the outside world and how to behave inside. And who is allowed in there. That didn't affect us personally. But it concerned me in terms of my understanding of social community /.../ The place was liberated for a specific purpose. It was to remain as such with these basic ideological rules /.../Things have changed. Now there are a lot of new people who are very engaged, and they are not controlled by one of the two big groups."

In the case of Tobačna, our interviewees mentioned they did not see the need to come together with other groups when people from the coworking space started with networking. An interviewee from a stone and soapmaking studio said they did not see Tobačna as the first choice for a place to work: "I had heard about a coworking space and thought it was cool what they were doing. It was quiet after we came here, but there's a lot going on with their commitment lately."

A similar case was observed in Metelkova. As the oldest district, it seems to attract fewer newcomers. A video and multimedia artist believes that certain activities are not part of the district: "The gay bar is not part of this district. Because the visitors are nothing other than public employees or entrepreneurs. Not that this is a bad thing, but 
they are no exception in the way they produce and consume culture. What they do is not the result of a free space. They use this space to avoid acts of violence that could happen elsewhere."

This is different from the beginning, when Mreža za Metelkovo was in need of studios, a space for rehearsals and a theatre venue, and therefore occupied the emptied military barracks. The collective did not want to exclude anyone, as one cultural activist explained: "Nobody knew that the Antifašistično društvo was going to move into Metelkova. They just showed up there."

The city administration understands the mobilisation and bundling of activities at the grassroots level differently from what we have observed in the districts. The senior city official noted that "Rog and Metelkova were formed spontaneously. Some of the actors from Metelkova moved to Rog when the building became the property of the city. There is now a public-private partnership solution to this story. Rog will become a centre of visual and creative industries."

\subsection{From solidarity and mutual assistance to forms of self-governance}

Mutual cooperation, help and support are the cornerstones of any successful artistic cluster. A representative of a fashion design collective from Križeuniška explained that she feels part of the district's community and that she can always rely on her neighbours: "If you need some ice and a few glasses when organising the catering for your event, all you have to do is ask the restaurant across the street. In the theatre, we can rent the technical equipment or arrange a parking permit. These examples are trivial, but they show the organic and spontaneous development of the neighbourhood."

Similarly, an employee of a letterpress studio in Križeuniška noted that they were immediately introduced to the other residents once the studio opened: "This is normally not the case for tenants who only pay rent and leave the apartment after the contract expires. I know most of the neighbours in this building and they ask me to water their flowers when they go on holiday and we warn each other about thieves. Our relationship is harmonious and cannot be compared to a business relationship."

An interviewee from a concert venue from Metelkova emphasised the importance of the performers sharing common goals: "One of the beauties of Metelkova is that everyone functions differently, but there is the common vision that unites us."

A member of a street dance group in Rog spoke about the importance of the Assembly, which is a new body recently established in the district: "The Assembly [Skupščina] has started 2 years ago to maintain momentum in times when the city council is planning to demolish Rog. It helps people work together and communicate."

A similar body, the Forum, has been set up in Metelkova with the mandate to set up ad hoc groups to deal with specific problems as they arise. Still, a video and multimedia artist holds mixed feelings about this body: "These groups are organised by people without any activity of their own, and they believe their purpose is to guide others. They create an atmosphere similar to that of companies or team-building sessions /.../ These things spontaneously lead away from autonomy into heteronomy and formal regulation."

Although the actors in both Metelkova and Rog hold very different views on how the autonomous community should function, it is clear that neither the Assembly nor the Forum should formally represent the district. This was confirmed by both the 
stakeholders and municipal officials: "We have made plans for our investments in Metelkova, but we cannot get them to come together and form a legal entity to talk to. They elude legal communication, yet at the same time the city administration cannot pursue informal channels of communication. That's why this issue has been pending for 20 years."

\subsection{Perceptions about neighbours: cooperation and complaints}

Each of the four arts districts observed in this study is located in the city centre, the commercial and administrative hub. Further, the districts are surrounded by buildings with apartments. Residents are accustomed to the noise of the surrounding streets due to numerous outdoor events, but the arts districts pose a particular challenge for the neighbourhood. The noise, which only stops late at night, keeps people from sleeping. The arts districts are also associated with drug abuse and anti-social behaviour. The interviewees were asked to talk about their relationship with residents in the neighbourhood.

A member of a collective for sound and visual arts, which moved from Rog to Tobačna, confirmed the constant problems they had with their neighbours: "I hope they take care of the neighbours. There was a rule not to argue with the neighbours and not to leave litter around. It was time for us to leave. We were there for quite a long time."

In contrast, a member of a street dance group said the relationship with the neighbours was fine: "The graffiti artists have a good neighbourly relationship with the owner of the villa next to Rog. She allows them to paint on the wall that Rog shares with her. She approves of this. I know some residents who live across the street. I live there too. Last week, some neighbours came to visit the factory [Rog]. The visits allow us to understand their opinions. The stigma that Rog is a place for drug users and homeless people is misguided. After 2004, the factory was 'cleaned up'."

The designers from the stone and soapmaking studio agreed that the district might be disturbing for the neighbours. Designer A: "I can imagine that the residents find it disturbing that some festivals are held here. I don't think they can benefit from it in any way." Designer B added: "I would agree with that. If in this case the festival organiser does not give the residents any advantages, then they will indeed find the whole thing disturbing." The representative of a concert venue confirmed that Metelkova produces a lot of noise: "People who are in the square in front of our venue produce constant noise, which is very disturbing. Nobody can benefit from it. In this sense, the local residents would benefit only if we were not there at all."

On the other hand, a representative of an immigrant support centre thinks the neighbours believe they benefit from the numerous activities at Rog: "There are many stereotypes about Rog. But our image has improved. On Neighbours' Day, at least 50 children came here with their parents and they enjoyed the visit." An interviewee from an LGBT rights group spoke about how an arts district such as Metelkoua can have a positive impact by increasing the value and quality of life in the neighbourhood: "This is a busy area, a stream of people from different generations. In my opinion, the quality of life here is relatively high. But it depends on what you want: peace and tranquillity or if you prefer a varied cultural offer." 


\subsection{Arts districts as a political struggle for an anti-capitalist and autonomous space}

Another recognisable theme is framed by cultural activism, reflected in the interrelationship between the claim to the workspace and the general spatial policy. In this section, we explain how actors give meaning to arts districts and how their affective atmospheres influence the politics of the urban space as a whole.

A cultural activist and concert organiser spoke about how the first city administration attempted to tear down everything involving communism in the early 1990s. Although Mreža za Metelkovo were promised rooms in Metelkova, they started with demolitions: "Our answer was resistance. At that time, an exchange between Utrech and Ljubljana took place under the motto Forbidden Fruits of Civil Society. There would be no occupation of Metelkova if it hadn't been fuelled by the Dutch squatters. /.../ It was about protecting people's property, which is more than just a public space. This was a burning issue at the time and remains so today. /.../ For us, it meant a place in the city centre where political debate and social action were possible."

A member of the Gallery and Platform for Plastic Arts further explained why Metelkova is a political space: "Metelkova was part of the political movement that experienced the 1990s. I am talking about the demilitarisation of Slovenia and its independence movement. The political initiatives that found their place here were important for the nation and socio-political developments in society. Activism was always present. Of course, there is also art and culture."

In 2006, a group of students and activists joined the TEMP initiative that decided to occupy the decaying factory of Rog bicycles and to give this space a new life. This was the result of many factors, including a new generation. Since the dissolution of Yugoslavia, many public spaces have disappeared and gentrification has taken place. This means that space is becoming auailable for those who can spend money. An interviewee from Rog's immigrant support centre further explained the political statement behind the occupation: "In this system, quite a lot of people have been pushed away. The occupation of this place was a political statement. Furthermore, there was a strong will at the grassroots level for such actions."

The construction of a broader meaning of arts and cultural place-making was explained by a representative of a circus collective: "Rog enables the production of art and culture that could not exist in a market system. This means that products which are important for society can only be produced in this space."

Creative thinkers and doers provide society with diverse opinions and convey values, but they also engage in thoughtful criticism of the political, economic and social system. A representative from one of the non-profit organisations emphasised: "We work in creative industries, but this also enables us to develop new ideas and projects that certainly have an impact on society. This potential to work on projects that have an impact on society encourages us to get involved as activists. /.../ We therefore felt obliged to support campaigns for same-sex marriage and other ideas that help to solve pressing social problems. /.../ The tobacco factory [where they work] was one of the first factories to help empower female workers. /.../ This karma of Tobačna is now transferred to us, who support the young population of precarious and independent women workers who will never find real work."

Autonomy, self-administration and the absence of hierarchy contribute to creative self-expression. This idea was explained in more detail by a concert organiser in Metelkova: "I see it as a place where anyone is welcome who is hardworking, competent 
and thinks outside the box. This is a place where you can develop and create something meaningful, where you can learn from someone working in the same field, and where you can work outside the usual constraints. We work in a bubble where everyone thinks the same. For me, Metelkova means freedom but also worry."

In a similar vein, a representative of a fashion design collective explained why she feels wonderful at Križeuniška: "The greening project, the idea that we want to become an arts district, and the way we try to work together, I find these things wonderful. People should connect and work together. That is the whole point of creativity. It brings joy to people-the artists have a place where they can present their work, and the visitors are happy too."

The freedom of expression and creativity was something that spontaneously founded the arts district of Metelkova. A representative of an LGBT group spoke about a free space that accommodated LGBT people: "Metelkova is a place of freedom, where you can exchange your thoughts and express yourself critically. It gives you a position outside the established system. You become an observer of the system. It is also a safe space in which a culture can develop that is not necessarily perfect and elitist. It stimulates artists and their genuine creativity."

\section{DISCUSSION AND CONCLUSION}

Hidden geographies manifesting during the examination of the spatial dimension of arts districts have thus far been subject to economics, sociological, or planning approach. The manifold aspects of the role of naturally-occurring arts districts in the struggle for the right to the city are discussed. Much remains to be done to fully understand their nature and relationship to city authorities and state regulation of public space. However, the four identified dimensions shed light on the role in the current academic and public debate on the relationship between market-driven urban development and the socio-cultural challenges that cities are facing.

Arts districts are not exclusive to the arts.

Arts districts are a complex community that seems to be most successful in production terms when it accepts anyone who wishes to be part of it. This includes activism, which is in line with the findings of Buser et al. (2013). Over time, however, such bundling of activities at the grassroots level begins to fade and discussions about who belongs to the district and who does not begin to become louder.

The Metelkova arts district has been recognised as an important case study as its history is well documented. In the almost three decades of its existence, the district has gone through several stages of development and experienced a change in political circumstances. While the first generation of squatters brought a breath of fresh air to the endless struggle for the just city, the district may over time become quite different. Initially, it received different profiles of artists and cultural workers, and a variety of activist collectives. As it had not experienced any generational change, the actors began to dictate who could become part of Metelkova and who did not fit with its 'philosophy'.

Nevertheless, our data suggest that organic and spontaneous cooperation between actors is a cornerstone of an attractive arts district. 
Autonomy contributes to creativity, but alternative forms of (self-)governance are not always supported by the actors.

Solidarity and support among actors was recognised as an important factor for a successful district. In line with previous findings (Garcia et al., 2015), our results show that a certain form of autonomy largely influences creativity. To fully immense in their work, actors tend to auoid any dictates by city authority or governmental bodies. Still, the arts districts developed some form of their own governance to establish some rules. These unofficial bodies are not accepted by everyone. Among the four districts, Metelkova and Rog developed governing bodies that are independent from city authority. Although their intention is clear (defining the main rules of the community), the actors tend to disagree on what is needed. Some also fear that this is all leading to them one day being ruled by a force outside the district.

Although the city benefits from arts districts, they are not appreciated by all neighbours.

Arts districts are described as contested sites within the city because in half of the cases (Metelkova and Rog) their development is associated with at least partial disapproval by the city administration and by a part of the public. Their presence remains a problem for some. We therefore looked more closely at the perception of the actors in relation to their neighbours and found that the noise they cause is the most sensitive aspect of good neighbourly relations. On the other hand, the presence of culture and arts in the neighbourhood maintains high property values and even poses the threat of gentrification.

\section{Ambiguous influence on the politics of space}

Arts districts are most successful when located in the central part of the city so as to ensure access to the market (visitors). Central areas are also most convenient for political debates and social actions. As confirmed by the interviewees, only such freedom of expression stimulates artists and their genuine creativity.

The changing character and development of the arts district was observed in Tobačna and Križeuniška. In contrast to Metelkova and Rog, the arrival of artists is due to the interest of private investors and the support of the city administration. They are also a good example of adequate support by the city in an organic arts-led urban development. Creating attractive conditions for the arrival of arts and culture at Tobačna may also be seen as the widely criticised approach of the investor to initiate a gentrification process. In the case of Tobačna, the private investor terminated the rental contracts in order to quickly transform this temporary, yet legally uncontroversial arts district into a business/residential estate of enormous value.

Soon after the former Rog bicycle factory got temporarily occupied, it attracted a great deal of public and media interest. There were several exhibitions, literature evenings, sports events, performances, and shows. Attendance was the highest in 2016, when the city administration attempted to demolish some building structures within Rog but met with strong resistance and several months of loud demonstrations accompanied by cultural, artistic and sporting events. These events were followed by public debates on who has the right to abandoned areas in the city centre. Our recent observations on the ground show that the number of public events has fallen sharply. 
We have also witnessed the usurpation of studios and rehearsal rooms by individuals and groups. Such events suggest that some forms of city authority interventions are needed to maintain and develop arts districts so that they remain urban commons and locale suitable not only for actors but also for visitors and neighbours. A challenge for the city authority is to plan such interventions through a participatory approach and to consider the expectations of public and private investors.

\section{ACKNOWLEDGEMENT}

The empirical part of the research took place during the author's employment at the Anton Melik Geographical Institute, Research Center of the Slovenian Academy of Sciences and Arts. The author would like to especially thank all of the participants for their interest and engagement in the interview process.

\section{REFERENCES}

Agnew, J. (1995). The hidden geographies of social science and the myth of the geographic turn. Environment and Planning D: Society and Space: 13: 379-380.

Babić, J. (2013). Metelkova mon amour. Reflections on the (Non-)Culture of Squatting. Časopis za Kritiko Znanosti: 41(253): 12-20.

Bartzokas-Tsiompras, A., and Photis, Y.N. (2020), Does neighborhood walkability affect ethnic diversity in Berlin? Insights from a spatial modelling approach, European Journal of Geography: 11(1), pp.163-187. https://doi.org/10.48088/ejg.a.bar.11.1.163.187

Bartzokas-Tsiompras, A., and Photis, Y.N. (2019), Measuring rapid transit accessibility and equity in migrant communities across 17 European cities. International Journal of Transport Development and Integration: 3 (3): https://doi.org/245-258. 10.2495/TDI-V3-N3-245-258

Bibič, B. (2003). Hrup z Metelkove: tranzicije prostorov in kulture v Ljubljani. Ljubljana: Mirouni inštitut.

Borch, C., and Kornberger, M. (Eds.) (2015). Urban commons: Rethinking the city. Routledge.

Borrup, T. (2016). Creative Placemaking: Arts and Culture as a Partner in Community Revitalization. In Fundamentals of Arts Management, ed. D. Boyle-Clapp, M. Brown, and M. Gard, 50-69. Amherst, MA: Arts Extension Service, University of Massachusetts.

Buser, M., Bonura, C., Fannin, M., and Boyer, K. (2013). Cultural activism and the politics of place-making. City: 17(5): 606-627. https://doi.org/10.1080/13604813.2013.827840

Currid, E., and Williams, S. (2010). Two cities, five industries: Similarities and differences within and between cultural industries in New York and Los Angeles. Journal of Planning Education and Research: 29(3): 322-335. https://doi.org/10.1177/0739456X09358559 
Ehrlich, K., Agnes K., and Thilo, L. (2012). Urban Development in Central and Eastern Europe - Betweeen Peripheralization and Centralization? The Planning Review: 48(2): 77-92.

Euans, G. (2009). Creative cities, creative spaces and urban policy. Urban studies: 46(56): 1003-1040. https://doi.org/10.1177/0042098009103853

Florida, R. (2002). Bohemia and Economic Geography. Journal of Economic Geography: 2(1): 55-71. https://doi.org/10.1093/jeg/2.1.55

García, M., Eizaguirre, S., and Pradel, M. (2015). Social innovation and creativity in cities: A socially inclusive governance approach in two peripheral spaces of Barcelona. City, Culture and Society: 6(4): 93-100. https://doi.org/10.1016/j.ccs.2015.07.001

Gordon, I. R., and McCann, P. (2000). Industrial clusters: complexes, agglomeration and/or social networks? Urban studies: 37(3): 513-532. https://doi.org/10.1080\%2F0042098002096

Halilouić, N., and Cerar, A. (2020). The rise and fall of creative revitalisation of the old Tobacco factory in Ljubljana, Slovenia. Urbact, 19 May 2020.

Hofmann, R., Mehren, M., and Uphues, R. (2012). Hacking the city: a somewhat different mode of field work. European Journal of Geography: 3(3): 23-32.

Kumer, P. (2020). Self-governance and social inclusion in a post-socialist city: Contradictions between city-designated and naturally-occurring arts districts. Teorija in praksa: 57(1): 389-406.

Lavanga, M. (2013). Artists in urban regeneration processes: use and abuse? Territoire en mouvement Reuue de géographie et aménagement. Territory in movement Journal of geography and planning: 17-18: 6-19.

Lefebure, H. (1968). Le droit à la ville (Vol. 3). Paris: Anthropos.

Markusen, A., and Gadwa, A. (2010). Creative placemaking. Washington, DC: National Endowment for the Arts.

Markusen, A., and Schrock, G. (2006). The artistic dividend: Urban artistic specialisation and economic development implications. Urban studies: 43(10): 1661-1686. https://doi.org/10.1080/00420980600888478

Mathews, V. (2010). Aestheticizing space: art, gentrification and the city. Geography Compass: 4(6): 660-675. https://doi.org/10.1111/j.1749-8198.2010.00331.x

Montgomery, J. (2003). Cultural quarters as mechanisms for urban regeneration. Part 1: Conceptualising cultural quarters. Planning, practice \& research: 18(4): 293-306.

Mreulje, N. (2015). Ljubljanska ulica z uznemirljivo preteklostjo in sedanjostjo. SiolNET, 11 June 2015.

Müller, A. L. (2019). Voices in the city. On the role of arts, artists and urban space for a just city. Cities: 91: 49-57. https://doi.org/10.1016/j.cities.2018.04.004

Murzyn-Kupisz, M. (2012). Cultural quarters as a means of enhancing the creative capacity of Polish cities? Some evidence from Cracow. Quaestiones Geographicae: 31(4): 63-76.

Niranjan, A. (2015): How an abandoned barracks in Ljubljana became Europe's most successful urban squat. The Guardian, 24 July 2015. 
Old Ljubljana Tobacco Factory Turning into New Art Centre (2015). The Slovenia Times, 23 September 2015.

Panjan, E. (2016): Rogouci in Jankouić ostajajo na nasprotnih bregouih. Dneunik, 25 May 2016.

Polèse, M. (2012). The arts and local economic development: can a strong arts presence uplift local economies? A study of 135 Canadian cities. Urban Studies: 49(8): 18111835.

Redaelli, E. (2019). Connecting Arts and Place: Cultural Policy and American Cities. Springer.

Rich, M. A., and Tsitsos, W. (2016). Auoiding the 'SoHo Effect' in Baltimore: neighborhood revitalization and arts and entertainment districts. International Journal of Urban and Regional Research: 40(4): 736-756. https://doi.org/10.1111/1468-2427.12376

Scott, A. J. (2008). Social economy of the metropolis: Cognitive-cultural capitalism and the global resurgence of cities. Oxford: Oxford University Press.

TOBACNA CITY (2012). Invest Slovenia, 12 June 2012.

Tosics, I. (2016). Squatting for cultural use toward commons: The case of Rog factory in Ljubljana. Urbact, 29 November 2016.

Vazquez, L. (2012). Creative placemaking: Integrating community, cultural and economic development. Montclair, NJ: The National Consortium for Creative Placemaking.

Verson, J. (2007). Why we need cultural activism. In Do it yourself: A handbook for changing our world, ed. Trapese Collective, 171-186. London: Pluto Press.

Webb, D. (2014). Placemaking and social equity: Expanding the framework of creative placemaking. Artivate: 3(1): 35-48.

Žagar, J. (2006). Metelkova (mesto). Diploma Thesis. Ljubljana: Fakulteta za družbene vede.

Zarlenga, M. I., Ulldemolins, J. R., and Morató, A. R. (2016). Cultural clusters and social interaction dynamics: The case of Barcelona. European Urban and Regional Studies: 23(3): 422-440. https://doi.org/10.1177/0969776413514592

Zukin, S., and Braslow, L. (2011). The Life Cycle of New York's Creative Districts: Reflections on the Unanticipated Consequences of Unplanned Cultural Zones. City, Culture and Society: 2(3): 131-140. https://doi.org/10.1016/j.ccs.2011.06.003 